\title{
Community-acquired Klebsiella pneumoniae meningitis in an alcoholic patient with an infected pancreatic pseudocyst; a case report and review of literature Adriana Orzechowska, Sandra Lacey, Geraldine Soosay and Mark Melzer*
}

Address: Department of Microbiology, King George Hospital, Goodmayes, Essex, UK

Email: Adriana Orzechowska - adrianaorzechowska@hotmail.com; Sandra Lacey - sandra.lacey@bhrhospitals.nhs.uk; Geraldine Soosay - geraldine.soosay@bhrhospitals.nhs.uk; Mark Melzer* - mark.melzer@bhrhospitals.nhs.uk

* Corresponding author

\author{
Published: 29 October 2007 \\ Received: 16 June 2007 \\ Journal of Medical Case Reports 2007, I:II6 doi:10.1 186/1752-1947-I-116 \\ Accepted: 29 October 2007 \\ This article is available from: http://www.jmedicalcasereports.com/content/1/1/116 \\ (c) 2007 Orzechowska et al; licensee BioMed Central Ltd. \\ This is an Open Access article distributed under the terms of the Creative Commons Attribution License (http://creativecommons.org/licenses/by/2.0), \\ which permits unrestricted use, distribution, and reproduction in any medium, provided the original work is properly cited.
}

\begin{abstract}
We report a case of a 49-year-old male with a history of chronic alcoholism and evidence of a pancreatic pseudocyst on CT scanning. He presented with a 3-days history of fever, loss of appetite and upper abdominal pain. Blood cultures grew Klebsiella pneumoniae and he improved clinically with a seven-day course of intravenous co-amoxiclav and metronidazole. Two weeks later he was readmitted to hospital with impaired consciousness and septic shock, and died three days later in intensive care. Post mortem examination revealed bacterial meningitis and an infected pancreatic pseudocyst. Klebsiella pneumoniae was isolated from the pancreas and meninges.
\end{abstract}

\section{Case report}

A 49-year-old man was admitted to hospital with a three day history of fever, loss of appetite and upper abdominal pain. He was of Indian origin, lived in the UK and denied any recent travel. Fifteen years previously, he was diagnosed with alcohol-related chronic pancreatitis. On admission his temperature was $38.5^{\circ} \mathrm{C}$, pulse rate $142 /$ minute, respiratory rate $24 /$ minute and blood pressure $116 / 80 \mathrm{mmHg}$. He was conscious and orientated and had no meningism. Abdominal examination revealed tenderness in the right hypochondrium. White blood count was $8.5 \times 10^{9} / \mathrm{l}$, haemoglobin $11.5 \mathrm{~g} / \mathrm{dl}$ and platelet count 200 $\times 10^{9} / \mathrm{l}$. His CRP was $38.5 \mathrm{mg} / \mathrm{L}$, albumin $32 \mathrm{~g} / \mathrm{L}$, bilirubin $16 \mathrm{umol} / \mathrm{L}$, alanine-aminotransferase (ALT) 24IU/L and amylase $48 \mathrm{IU} / \mathrm{L}$. Urinalysis revealed no nitrites or leucocytes. Blood cultures grew Klebsiella pneumoniae, resistant to ampicillin but susceptible to amoxicillin/clavulanic acid by BSAC disc diffusion methods. Abdominal CT scan with contrast revealed evidence of a pseudocyst in the pancreas but no evidence of infection. Radiologically, there was no evidence of cholelithiasis, obstruction of the common bile duct or cholecystitis. Intravenous (iv) antibiotics, amoxicillin/clavulanic acid $1.2 \mathrm{~g}$, thrice daily, (tds) and metronidazole $500 \mathrm{mg}$ tds, were commenced with one dose of gentamicin $400 \mathrm{mg}$ (iv). Antibiotics were continued for seven days. The patient improved clinically and was discharged home. The source of his bacteraemia remained undefined.

Two weeks later the patient was readmitted with a four day history of rigors. On admission, his temperature was $40^{\circ} \mathrm{C}, \mathrm{O}_{2}$ saturation $98 \%$, pulse $142 / \mathrm{min}$ and $\mathrm{BP} 140 / 90$. White cell count was $10.6 \times 10^{9} / \mathrm{l}$, haemoglobin $10.6 \mathrm{~g} / \mathrm{dl}$ and platelet count $199 \times 10^{9} / \mathrm{l}$. His CRP was elevated at $236.1 \mathrm{mg} / \mathrm{L}$. Liver function tests were normal. Blood culture again grew Klebsiella pneumoniae, resistant to ampicillin. Prior to blood culture results, empirical treatment with piperacillin/tazobactam (iv) $4.5 \mathrm{~g}$ tds was com- 
menced. Four hours later, the patient became unresponsive and his Glascow Coma Score (GCS) fell to 6/15. An arterial blood gas revealed metabolic acidosis with respiratory compensation. CT scan of the head was normal. The patient was transferred to ITU, intubated, ventilated and maintained on the same antibiotic regime. Two days later he died. A post mortem revealed an infected pancreatic pseudocyst and bacterial meningitis. Tissue and pus from both sites grew Klebsiella pneumoniae. Pancreatic, blood and meningeal $K$ pneumoniae isolates were sent for typing to the UK Health Protection Agency (HPA) Enteric Pathogen laboratory. All isolates had indistinguishable serotypes (K2) and a pulse field gel electrophoresis pattern designated 'King 15'.

\section{Discussion}

Like other members of the family enterobacteriaceae, $K$ pneumoniae causes infection of bile and urine, sterile fluids in close proximity with the gastrointestinal tract. Complications of primary sites of infection are uncommon but liver and prostatic abscesses do occur. Dissemination of $K$. pneumoniae to secondary sites is rare but septic arthritis, vertebral osteomyelitis and endophthalmitis have been described.

In adults, $S$. pneumoniae and $N$. meningitides are the commonest causes of bacterial meningitis. Bacterial meningitis caused by $K$. pneumoniae is uncommon but some cases have been reported, especially in Taiwan. Over a four-year period, 27 Taiwanese patients were diagnosed with $K$. pneumoniae meningitis[1] and in another Taiwanese case series conducted over six years, the proportion of K. pneumoniae as a cause of bacterial meningitis rose from $8 \%$ to $18 \%[2]$. Underlying co-morbidities included diabetes, alcoholism and chronic liver disease[1-4]. Outside Taiwan, cases of $K$. pneumoniae meningitis have occurred, predominantly in other parts of Asia [5-7] but also in Europe [8-11] and North America [12-14]. The rarity of these cases outside Asia raises the possibility of ethnicity or country of origin predisposing individuals to invasive disease[15].

Phenotypically, K. pneumoniae isolates with hypermucoviscosity are, 'in-vivo', anti-opsonic, anti-phagocytic and associated with severe disease[16]. Isolates with $\mathrm{K} 1$ and $\mathrm{K} 2$ capsular antigens are the most invasive pathogens. These capsular serotypes, rather than the genes magA and rmpA that regulate extracapsular polysaccharide synthesis, are probably the most important virulence determinants for K. pneumoniae[17].

Clinical outcomes are poor in cases of $K$ pneumoniae meningitis despite adequate and prolonged antibiotic treatment. Different choices of empirical intravenous cephalosporins do not alter clinical outcomes[18]. In the fore-mentioned case series, other prognostic factors of patients were analysed. Time from onset of symptoms to start of appropriate therapy, disease severity, age, gender, diabetes mellitus, acquisition settings and antibiotic resistance were not significantly correlated with survival. The only determinant of a better neurological and clinical outcome was the timing of the first dose of appropriate antibiotic given before levels of consciousness fell below a GCS of eight.

Pancreatic pseudocysts are an uncommon complication of pancreatitis. They arise from disruptions of the pancreatic duct due to pancreatitis and extravasation of enzymatic material. Over $75 \%$ of cases are caused by alcohol and most pseudocysts resolve spontaneously. The optimal management of pancreatic pseudocysts remains debatable although drainage should be performed when symptoms persist or complications arise. Infection occurs in approximately $10 \%$ of cases [19] and this is an indication for drainage which can be achieved endoscopically or at open surgery.

\section{Conclusion}

To our knowledge this is the first case of an infected pancreatic pseudocyst to cause K. pneumoniae bacteraemia. Remarkably, it caused bacterial meningitis following initial clinical improvement with a seven-day course of appropriate antibiotics. Had we suspected the pseudocyst was infected we would have advised drainage and a longer course of treatment. Rarely, outside Asia, and in alcoholic patients with underlying co-morbidities, virulent strains of $K$. pneumoniae may disseminate from primary sites of infection and cause bacterial meningitis.

\section{Competing interests}

The author(s) declare that they have no competing interests.

\section{Authors' contributions}

$\mathrm{AO}$ wrote the case history and researched the discussion. MM and SL were involved in the patient's management and gave antimicrobial advice. GS performed the post mortem. All authors have read and approved the final manuscript.

\section{Consent}

Written informed consent was obtained from the patient's relative for publication of this case report.

\section{References}

I. Lee PY, Chang WN, Lu CH, Lin MW, Cheng BC, Chien CC, Chang $\mathrm{CJ}$, Chang HW: Clinical features and in vitro antimicrobial susceptibilities of community-acquired Klebsiella pneumoniae meningitis in Taiwan. J Antimicrob Chemother 2003, 5 1:957-962.

2. Tang LM, Chen ST, Hsu WC, Chen CM: Klebsiella meningitis in Taiwan: an overview. Epidemiol Infect 1997, I 19:135-42. 
3. Lu CH, Chang WN, Wu HS: Klebsiella pneumoniae meningitis: Analysis on Clinical Features of Thirty-two Adults Patients. Chin Med J 1997, 60:296-302.

4. Shih HI, Lee HC, Chuang CH, Ko WC: Fatal Klebsiella pneumoniae Meningitis and Emphysematous Brain Abscess after Endoscopic Variceal ligation in a Patient with Liver Cirrhosis and Diabetes Mellitus. J Formos Med Assoc 2006, 10:857-860.

5. Ohmori S, Shiraki K, Ho K, Inoue H, Ito T, Sakai T, Takase K, Nakano $\mathrm{T}$ : Septic endophthalmitis and meningitis associated with Klebsiella pneumoniae liver abscess. Hepatol Res 2002 22(4):307-I2.

6. Honma $Y$, Shiraishi M, Yanagisawa T, Maki F, Sugihara H, Takahashi $Y$, Otsuka Y: A case of ventriculitis with bacterial meningitis that occurred during treatment of a liver abscess. Kansenshogaku Zasshi 2003, 77(I I):977-8I.

7. Yanagawa T, Nakamura H, Takei I, Maruyama H, Kataoka K, Saruta T, Kobayashi T: Klebsiella pneumoniae meningitis associated with liver abscess: a case report. Jpn J Antibiot 1989, 42(10):2। $35-40$

8. Troncoso Garcia E, Munoz Medina L, Callejas Rubio JL, Lopez Ruz MA: Klebsiella pneumoniae meningitis, Strongyloides stercoralis infection and HTLV-I. Med Clin (Barc) 2000, I I 5(4):I 58.

9. Bousdma L, Schortgen F, Thomas R, Wutke S, Lellouche F, Regnier B, Wolff M: Adults with spontaneous aerobic Gram-negative bacillary meningitis admitted to the intensive care unit. Clin Microbiol Infect 2006, I 2(3):287-90.

10. Giobbia M, Scotton PG, Carniato A, Cruciani M, Farnia A, Daniotti E, Scarpa G, Vaglia A: Community-acquired Klebsiella pneumoniae bacteraemia with meningitis and endophthalmitis in Italy. Int J Infect Dis 2003, 7(3):234-5.

1I. Sandyk R, Brennan MJ: Unusual presentation of primary klebsiella meningitis: successful treatment with cefotaxime. Postgrad Med J 1983, 59(690):256-7.

12. Saccente M: Klebsiella pneumoniae liver abscess, endophthalmitis and meningitis in a man with newly recognized diabetes mellitus. Clin Infect Dis 1999, 29(6): 1570-I.

13. Braiteh F, Golden MP: Cryptogenic invasive Klebsiella pneumoniae liver abscess syndrome. Int J Infect Dis 2007, I I (I): 16-22.

14. Holder CD, Halkias D: Relapsing bacteraemic Klebsiella pneumoniae meningitis in an AIDS patient. Am J Med Sci 1988, 295(I):55-9.

15. Ko WC, Paterson DL, Sagnimeni AJ, Hansen DS, Von Gottberg A Mohapatra S, Casellas JM, Goosens H, Mulazimoglul L, Trenholme G, Klugman KP, McCormack JG, Yu VL: Community-Acquired Klebsiella pneumoniae bacteraemia: global differences in clinica patterns. Emerging Infectious Diseases 2002, 8(2):160-6.

16. Lee HC, Chuang YC, Yu WL, Lee NY, Chang CM, Ko NY, Wang LR, Ko WC: Clinical implications of hypermucoviscosity phenotype in Klebsiella pneumoniae isolates: association with invasive syndrome in patients with community-acquired bacteraemia. J Intern Med 2006, 259(6):606-I4.

17. Yeh KM, Kurup A, Siu LK, Koh YL, Fung CP, Lin JC, Chen TL, Chang FY, Koh TH: Capsular serotype KI or K2, rather than magA and rmpA, is a major virulence determinant for Klebsiella pneumoniae liver abscess in Singapore and Taiwan. J Clin Microbiol 2007, 45(2):466-7I.

18. Fang CT, Chen YC, Chang SC, Sau WY, Luh KT: Klebsiella pneumoniae meningitis: timing of antimicrobial therapy and prognosis. Q J Med 2000, 93:45-53.

19. Hakaim AG, Broughan TA, Vogt DP, Hermann RE: Long-term results of the surgical management of chronic pancreatitis. Am Surg 1994, 60:306-8.
Publish with Biomed Central and every scientist can read your work free of charge

"BioMed Central will be the most significant development for disseminating the results of biomedical research in our lifetime. "

Sir Paul Nurse, Cancer Research UK

Your research papers will be:

- available free of charge to the entire biomedical community

- peer reviewed and published immediately upon acceptance

- cited in PubMed and archived on PubMed Central

- yours - you keep the copyright

Submit your manuscript here:

http://www.biomedcentral.com/info/publishing_adv.asp
BioMedcentral 